\title{
MANIFESTAÇÕES ARTísticAs dE LATINOS NOS ESTADOS UNIDOS: \\ FORMAS PARA CRUZAR FRONTEIRAS
}

\author{
Latino artistic production in the United States: \\ ways across frontiers
}

\author{
Giséle Manganelli Fernandes*
}

Nothing happens in the "real" world unless it first happens in the images in our heads. (Gloria Anzaldúa, 1999, p. 109)

Indubitavelmente, os latinos constituem um grupo forte de imigrantes nos Estados Unidos hoje. Oriundos de várias regiões diferentes, eles precisam encontrar uma forma de união a fim de que possam mostrar as causas pelas quais lutam e também firmar suas posições na sociedade americana.

A arte, então, torna-se uma maneira de concretizar este objetivo, isto é, a produção artística destes imigrantes e de seus descendentes revela suas lutas por conquistas sociais e sua busca por uma identidade no contexto em que se encontram.

Os latinos já adquiriram relevância social e política e, há anos, têm conseguido eleger prefeitos, governadores e representantes no Congresso. Todos os candidatos ao cargo de Presidente dos Estados Unidos reconhecem a importância deste segmento de eleitores para o sucesso de sua campanha.

Neste trabalho, analisaremos textos que nos auxiliam a refletir sobre as angústias e lutas deste grupo na América.

Ora, se o mundo contemporâneo não pode mais ser imaginado sem o debate a respeito do contato entre culturas, colocando em xeque

* UNESP-SJRP 
tradições, valores, costumes, crenças, identidades, o "cruzar fronteiras", por esta razão, passou a ter um significado mais amplo do que apenas atravessar limites geográficos. Para Tomaz Tadeu da Silva, "'Cruzar fronteiras' significa não respeitar os sinais que demarcam 'artificialmente' os limites entre os territórios das diferentes identidades" (2000, p. 88). E a arte possibilita esta forma de "cruzar fronteiras".

Para iniciar a nossa discussão, tomemos três escritores: Rodolfo "Corky" Gonzalez, Gloria Anzaldúa e Guillermo Gómez-Peña. Estes artistas Chicanos ${ }^{1}$ mostram posturas combativas em seus textos.

Rodolfo "Corky" Gonzalez, em seu poema "I am Joaquín" ${ }^{2}$ apresenta um sujeito em conflito com a realidade. Joaquín encontra-se "lost in a world of confusion", dividido entre suas tradições e as atitudes da "gringo society" (ORTEGA, 2001, p. 145), que o oprime e manipula.

Entretanto, Joaquín mostra que embora seus ancestrais tenham perdido a batalha em termos econômicos, ganharam "the struggle of cultural survival" (2001, p. 145). Esta é a grande força motora dos latinos: sua cultura antiquíssima, que os impulsiona na luta pela sobrevivência e fortalecimento de seu povo.

Joaquín, definindo-se como "the eagle and serpent of the Aztec civilization" (p. 145), é "Cuahtémoc", o último imperador dos Astecas, cujo nível de civilização estava mais avançado do que Cortés ("the despot") poderia sonhar.

o sangue de Joaquín jorra por muitos motivos desde Montezuma. As fortes marcas vermelhas da escravidão indígena ainda permanecem em suas costas. A pureza do sangue indígena foi derramada pela ação do chicote dos brancos, que julgaram e condenaram os índios à destruição. Hoje, na corte de justiça social branca, Joaquín está sentenciado ao desespero, sem dinheiro. Porém, ele permanece forte no orgulho e "rich in courage" (2001, p. 146). A oposição pobreza/riqueza no poema serve para contrapor o poderio econômico branco que subjuga La Raza. Os primeiros são ricos em bens materiais; os segundos, em "spirit and faith" (2001, p. 146). Temos, então, duas formas de prosperidade: uma ligada ao capital e, outra, aos valores morais e espirituais, esquecidos por quem coloca o materialismo acima do idealismo, isto é, os brancos.

Joaquín denuncia que enriqueceu "o Anglo", o materialista. Este mesmo branco que causou a Joaquín a perda de sua terra e o "estupro" de sua cultura, na guerra travada entre os Estados Unidos e o México. Hoje, desprovidos do apoio dos brancos que tornou ricos, muitos imigrantes, sem social e político.

Mexicanos ou descendentes de mexicanos que vivem nos Estados Unidos e têm engajamento latinos/joaquin.htm.

Este poema foi consultado em duas fontes: ORTEGA e http://www.latinamericanstudies.org/ 
outra alternativa, acabam ingressando no "welfare" (2001, p. 146) e sendo presos por cometerem crimes.

Em busca da união por uma causa comum é expressa no seguinte trecho:

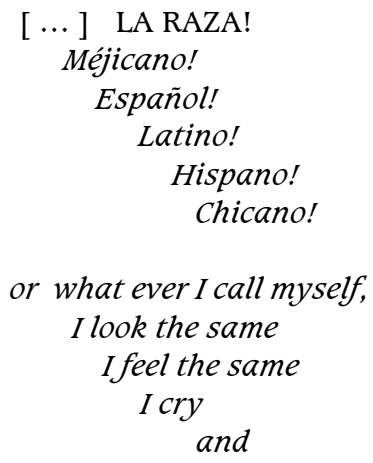

Não importando como se refere a si mesmo (ou como é chamado pelos outros), Joaquín representa, antes de tudo, "La Raza", que luta contra a opressão e se recusa a ser dissipada pela cultura hegemônica.

o poema termina com as afirmações:

\section{SHALL ENDURE!}

I WILL ENDURE!

(ORTEGA, 2001, p. 146)

Esta convicção de Joaquín emerge da força da mistura de possibilidades, pois ele firma ser "Aztec prince and christian Christ" (2001, p. 146). Daí eclode a energia para a resistência.

Resistência que, para Gloria Anzaldúa, está no surgimento de uma "new mestiza consciousness, una consciencia de mujer" (1999, p. 99). Em seu livro Borderlands/La Frontera: The New Mestiza (1987), escrito em Inglês e em Espanhol, Gloria Anzaldúa discute (assim como Rodolfo Gonzalez), as injustiças cometidas desde a época da guerra dos Estados Unidos contra o México, quando os mexicanos perderam regióes onde hoje estão o Texas, o Colorado, o Novo México e a Califórnia. Atualmente, os mexicanos migram para o norte, em um processo de retorno a um território que já lhes pertenceu.

A autora mostra a conexão verdadeira que os chicanos têm com a terra ao descrever seus momentos de infância, quando ajudavam os pais no plantio e na colheita: 
FERNANDES, G. M. MAnifestações ARtísticas de Latinos nos Estados Unidos...

Yes, the Chicano and Chicana have always taken care of growing things and the land. Again I see the four of us kids getting off the school bus, changing into our work clothes, walking into the field with Papi and Mami, all six of us bending to the ground. Below our feet, under the earth lie the watermelon seeds. We cover them with paper plates, putting terremotes on top of the plates to keep them from being blown away by the wind. [...] We water them and hoe them. We harvest them. The vines dry, rot, are plowed under. Growth, death, decay, birth. The soil prepared again and again, impregnated, worked on. A constant changing of forms, renacimientos de la tierra madre.

This land was Mexican once, was Indian always

and is.

And will be again. (ANZALDÚA, 1999, p. 113)

Neste final, Anzaldúa remonta a um passado bem anterior ao de seus pais, na época em que aquelas terras ainda pertenciam ao México. Entretanto, a autora mostra sua confiança de que eles voltarão a possuir as faixas de terra perdidas e poderão cultivá-las como antigamente, desde o tempo dos índios.

Portanto, os leitores podem verificar que a fronteira México-Estados Unidos é bastante problemática, pois ali permanece um forte sentimento de perda: "we were jerked out by the roots, truncated, disemboweled, dispossessed, and separated from our identity and our history" (1999, p. 30). A tensão expressa nestas linhas revela a postura de Anzaldúa contra aqueles que retiraram os mexicanos habitantes daquela área, separando-os de sua própria história. Contudo, ela ainda nutre um sentimento afetuoso por aquela fronteira:

How I love this tragic valley of South Texas, as Ricardo Sánchez calls it: this borderland between the Nueces and the Rio Grande. This land has survived possession and ill-use by five countries: Spain, Mexico, the Republic of Texas, the U.S., the Confederacy, and the U.S. again. It has survived Anglo-Mexican blood feuds, lynchings, burnings, rapes, pillage. (ANZALDÚA, 1999, p. 112)

Por esses motivos, Anzaldúa conclama os chicanos a resistirem e lutarem contra todos os tipos de opressão, pois a vitória será alcançada:

We know how to survive. [...] We know what it is to live under the hammer blow of the dominant norteamericano culture. But more than we count the blows, we count the days the weeks the years the 
FERnAndes, G. M. Manifestações Artísticas de Latinos nos Estados Unidos...

centuries the eons until the white laws and commerce and customs will rot in the deserts they've created, lie bleached. [...] Stubborn, persevering, impenetrable as stone, yet possessing a malleability that renders us unbreakable, we, the mestizas and mestizos, will remain. (ANZALDÚA, 1999, p. 85-86)

Anzaldúa acredita nesta força mestiça que determinará o final de anos de submissão. Esta tolerância por percorrer culturas distintas proporcionará o entendimento necessário para a sua sobrevivência no mundo de inclusões, de diversidade e não mais na existência de uma "raça pura".

Ainda mais relevante para a autora é "la consciencia de la mestiza". Esta nova mulher mestiça deve romper com a opressão masculina imposta pela tradição, pois

\begin{abstract}
She reinterprets history and, using new symbols, she shapes new myths. She adopts new perspectives toward the darkskinned, women and queers. She strengthens her tolerance (and intolerance) for ambiguity. She is willing to share, to make herself vulnerable to foreign ways of seeing and thinking. [...] Se hace moldeadora de su alma. Según la concepción que tiene de sí mesma, así será. (ANZALDÚA, 1999, p. 104-105)
\end{abstract}

A autora propõe que a mulher busque seu próprio caminho e não aceite a chamada "superioridade" do homem imposta pela cultura machista. Segundo Arteaga, "Anzaldúa cites the new mestiza's tolerance for ambiguity as the very means to oppose the closed texts of Western binarism that prescribe heterosexuality, patriarchal authority, and intolerance for deviation" (1997, p. 34-35).

Por pertencer a uma mescla de culturas, "the new mestiza" deve estar preparada para outros modos de analisar o mundo, com a flexibilidade que adquiriu por estar "in all cultures at the same time" (ANZALDÚA, 1999, p. 99), embora tenha de enfrentar uma luta interior em busca de sua identidade.

Anzaldúa define-se como uma "rebelde", "queer", filha da Malinche, da "Chingada" (e não da Virgem de Guadalupe), que utiliza sua escrita para denunciar sua postura contra estruturas pré-estabelecidas. Escrever é a maneira que Anzaldúa encontrou para dar voz a quem esteve silenciado por muito tempo chicanos, latinos, mulheres e homossexuais. A autora afirma que "Writing produces anxiety. Looking inside myself and my experience, looking at my conflicts, engenders anxiety in me. Being a writer feels very much like being a Chicana, or being a queer a lot of squirming, coming up against all sorts of walls" (1999, p. 94). 
FERnANDES, G. M. MAnifestações ARtísticas de Latinos nos Estados Unidos...

Os Chicanos são híbridos e, neste sentido, Arteaga salienta que

The Chicano is at once mestizo and Indian, and the mestizo and Indian lives in the United States and /or Aztlán and speaks English and/or Spanish. And beyond this, the subject is hybridized, meaning that there is always the possibility of the subject's active participation in that definition. (ARTEAGA, 1997, p. 18).

Arteaga também assinala que esta mestiçagem pode representar uma esperança de entendimento da diversidade: "Aztlán and the borderlands are therefore not the impossibilities they are for the nation states of the United States and Mexico but the open possibility for negotiating difference" (1997, p. 17). Esta possibilidade de negociação é fundamental no mundo globalizado.

Essa sensação de ambiguidade é difícil de ser resolvida, mas, justamente por haver esta convergência de diversas origens e culturas é que podemos pensar em alguma forma de entendimento entre os povos.

Outro aspecto relevante a ser abordado é a mescla de línguas utilizadas nos textos. O fato de escreverem em Inglês e em Espanhol revela a divisão cultural em que vivem os escritores chicanos e latinos. Os artistas criam pelo sofrimento de estarem divididos entre duas culturas. Segundo Arteaga,

Chicano poetry has opted for hybridization, a linguistic mestizaje, incorporating the languages and discourses at play in America. It tends to reject the monologue of either autocolonial, assimilationist, English-only verse or the monologue of nationalist Spanish-only verse. Instead, it opts for a multiple tongue, multivoiced literature of the border. (ARTEAGA, 1997, p. 88)

Guillermo Gómez-Peña, um outro artista Chicano, em sua obra The New World Border: Prophecies, Poems, and Loqueras for the End of the Century (1996), refere-se a um futuro sem fronteiras: "I see a whole generation/freefalling toward a borderless future” (1996, p. 1).

Ainda sobre fronteiras, vejamos a abordagem de Guillermo Gómez-Peña:

I make art about the misunderstandings that take place at the border zone. But for me, the border is no longer located at any fixed geopolitical site. I carry the border with me, and I find new borders wherever I go. (GÓMEZ-PEÑA, 1996, p. 5) 
Portanto, as fronteiras para as relações entre culturas, línguas, ideologias, crenças encontram-se em estado de erosão.

Gómez-Peña ainda opõe a concepção de "New World Order" pelo conceito de "New World Border" "a great trans-intercontinental border zone, place where no centers remain". Com isso, "hibridity is the dominant culture" (1996, p. 7). A proposta do autor ainda inclui a noção de um "Fourth World" em substituição ao "First World/Third World". No "Fourth World", haveria pouco espaço para "static identities, fixed nationalities, 'pure' languages, or sacred cultural traditions" (1996, p. 7).

Esta seria uma situação ideal para o futuro, pois as barreiras teriam sido abolidas e haveria uma maior integração entre os povos. 0 hibridismo seria a regra contra a raça pura e as identidades e nacionalidades se misturariam e as diferentes culturas se interpenetrariam facilmente.

A concepção de América para o autor já é diferente. Para ele, América "includes different people, cities, borders, and nations" (1996, p. 5). Nesta "nova fronteira mundial"

\begin{abstract}
the process of balkanization that Eastern Europe underwent from 1989 to 1992 are projected onto the United States: dozens of micro-republics pop up everywhere; the U.S.-Mexico border disappears; Spanglish becomes the "official" language; the hybrid state is now a political reality; and the ethnic/social pyramid has been turned upside down. (GÓMEZ-PEÑA, 1996, p. 21)
\end{abstract}

O fato de os mexicanos (e outros latinos) estarem cada vez mais presentes na vida cotidiana dos americanos torna necessária uma nova perspectiva para enfrentar a realidade. Os Estados Unidos estão em um processo de hibridismo. Não é mais possível ignorar que os imigrantes têm sua importância na economia americana.

Gómez-Peña aborda a questão dos mexicanos que trabalham ilegalmente nos Estados Unidos. Segundo o autor, os ilegais contribuem para a indústria de construções, nas colheitas de laranja, tomates e outros produtos, na limpeza de restaurantes e bares, no cuidar de crianças e acrescenta que "the list of underpaid contributions by 'illegal aliens' is so long that the lyfestyle of many Americans couldn't possibly be sustained without them" (1996, p. 68).

Gómez-Peña aponta em seu livro não somente Newt Gingrich, mas também Pat Buchanan, entre outros, que são contra iniciativas como a educação bilíngue, clamando que os Estados unidos não devem cair em um processo de "Third-Worldization" (1996, p. 173).

Entretanto, acordos econômicos são feitos com o México, tais como o The North American Free Trade Agreeement (NAFTA) e, então, o México 
passa a ser relevante para Estados Unidos e Canadá, não tendo a menor importância a grande diferença econômica entre aquele e estes países. Com isto, Gómez-Peña mostra que o México pode se tornar uma "megamaquiladora [assembly plant] or, as Chicana artist Yareli Arismendi has stated, 'the largest Indian reservation of the United States'" (1996, p. 8), caso não seja tratado como igual perante os parceiros ricos. Portanto, podemos observar que o autor tem posições políticas bastante firmes no que se refere à relação México-Estados Unidos em diversos aspectos, tais como o cultural, o educacional e o econômico.

Com uma postura mais relacionada ao sentimento de estar dividido entre duas culturas, o cubano-americano Gustavo Pérez Firmat, em seu poema "Cura de Cuba", mostra como tenta curar-se de seu país de origem, mas

Mi interes, mi fé, mi devoción, mi amor hacia Cuba, por capciosa o caprichosa que sea la idea que me he formado de ese despreciable país, es un tipo de fanatismo o idolatria - origen, según Cioran, de todas las crueldades de la historia. (MCILVOY, 2004, p. 126)

O poeta constata sua impossibilidade de negar sua origem, porque ainda ama Cuba, e sofre com as condições em que sua terra natal se encontra: "ese despreciable pais".

Seu texto continua por mostrar que sua divisão entre Cuba e os Estados Unidos leva-o a questionar-se sobre quem ele é, a sua identidade: "Ser cubano (ipero es que soy cubano?) es parte tan fundamental de quien soy, que al quedarme sin Cuba me quedo sin mí. No importa. Hace tiempo ya que vivo sin mí" (2004, p. 126).

o fato de viver "sem Cuba" o faz viver sem quem ele pensava que era. A imagem de si mesmo está prejudica, transformada, confusa. Ele já não mais se reconhece como cubano, porém, não se sente americano. Ora, ele tem vivido sem "si" mesmo, tornando-se um ser entre duas culturas. Ele afirma que se Cuba é "despreciable", ele também o é. Ele encontra dificuldades em deixar as suas origens para tornar-se um americano, aceitando os valores americanos como seus.

Por mais que a sua razão queira curá-lo de Cuba, seu yo não pode ser libertado de seus pensamentos e não será. o poeta afirma que "Years ago I wrote, 'North Carolina is also Caribbean,' The sentence is a symptom of my illness, this sick need to wrap in Cuba even when and where Cuba is not" (2004, p. 127).

E conclui que 
FERnAndes, G. M. Manifestações Artísticas de Latinos nos Estados Unidos...

The alternative to Cuba is silence.

Dos patrias tengo yo: el silencio y la noche. (MCILVOY, 2004, p. 127)

Assim, vemos que o autor tenta, de modo desesperado, esquecerse de Cuba, mas isto não é possível. Cuba é ainda sua mãe-pátria, na qual ele quer "embrulhar-se", sentir-se seguro. A alternativa que lhe resta é o "silêncio", que os Estados Unidos representam para ele, já que cuba é a "noite". Ele não encontra satisfação nem em Cuba, nem nos Estados Unidos. Ele está deslocado no mundo, buscando sua identidade.

Em um outro poema, "Mumble King", Pérez Firmat escreve suas reflexões sobre o ser cubano-americano:

\author{
Cubano-americano: ¿dónde soy? \\ son que se fue de Cuba \\ corazón que dejé enterrado \\ riconcito de mi tierra \\ pedacito de cielo: ¿dónde soy? \\ Un extraviado \\ Un faccioso \\ Un inconforme \\ Un dividido \\ cuba: no \\ america: no \\ ¿Dónde soy? \\ (MEDINA, 2005, p. 29)
}

Nesta parte do poema, verificamos como o poeta está inconformado com sua condição e afirma ser "um dividido", sem saber onde se encontra. o seu coração, entretanto, ficou em Cuba. A sensação de desconforto vivida pelo poeta torna-se evidente.

Por meio da análise dos textos foi possível verificar que os autores abordam as angústias, as incertezas e as dificuldades que os imigrantes enfrentam para romper com as tradições de seus ancestrais. A busca pela identidade acentua os questionamentos referentes aos modos pelos quais os imigrantes latinos são vistos nos Estados Unidos, mormente os ilegais. Ao mesmo tempo em que estes imigrantes exercem atividades importantes para a economia daquele país, são discriminados por representarem mais despesas com impostos para o contribuinte americano. E mesmo o imigrante cuja situação já está regularizada sofre algum tipo de preconceito.

Neste mundo globalizado, mais do que nunca antes visto, tornase crucial entender o Outro, respeitar diferenças, e todos nós devemos considerar, de fato, como tratar aqueles que imigram em busca de uma 
melhor condição de vida. Estas pessoas precisam se sentir respeitadas e aceitas como cidadãos, sem serem pré-julgadas. Elas devem receber uma chance de se integrarem na comunidade em que vivem, sem serem vistas como diferentes, como se não pertencessem a nenhum lugar. Os textos que foram abordados neste trabalho desafiam o poder de interpretação dos leitores e, consequentemente, eles podem refletir e transformar suas atitudes em relação ao momento histórico presente e de estarem prontos para o que o futuro exigirá deles em termos de atitudes para criar uma sociedade mais solidária, menos alienada em relação aos problemas alheios e, portanto, mais justa e com oportunidades para todos.

\title{
RESUMO
}

Questões de fronteiras passaram a constituir um assunto importante no mundo contemporâneo, uma vez que a globalização tornou indistintas as noções de limites entre culturas e economias. Os imigrantes sempre tiveram de enfrentar o problema de cruzar fronteiras e isto os levou a serem colocados frente a frente com questões relativas à identidade. Nos Estados Unidos, os textos produzidos por imigrantes latinos ou por americanos de origem latina têm revelado suas ansiedades e seus desconfortos quando são colocados em confronto com o debate a respeito de romper com as tradições de seus ancestrais e de se acostumarem a um estilo de vida diferente. Por meio de textos de Gloria Anzaldúa, Guillermo Gómez-Peña, e Gustavo Pérez-Firmat, este trabalho examina a divisão entre o sistema de valores herdado pelos latinos e o que eles devem obedecer na América. A utilização de duas línguas, Inglês e Espanhol, reforça um estilo de vida marcado por uma mistura de costumes, ideais e culturas e também apresenta uma união problemática entre duas realidades complexas. Este estudo aborda a importância da literatura produzida pelos latinos nos Estados Unidos, pois seus escritos apontam as contribuições da imigração latina na vida cultural e social dos americanos.

Palavras-chave: Fronteiras; Identidade; Literatura produzida por Latinos nos Estados Unidos.

\begin{abstract}
Frontier matters have become an important issue in contemporary world, since globalization has blurred the notion
\end{abstract}


of cultural and economic boundaries. Immigrants have always had to deal with the problem of border crossing, which had has led them to face questions related to identity issues. In The United States, the works produced by Latino immigrants and by American writers of Latino origin have shown the anxieties and uneasiness they are confronted with when the debate is on breaking up with the traditions of their ancestors and getting used to a different way of life. The purpose of this paper is to analyze how texts by Gloria Anzaldúa, Guillermo Gómez-Peña, and Gustavo Pérez-Firmat reveal the division between the system of values inherited by latinos and the one they have to follow in America. The usage of two languages, English and Spanish, reinforce a lifestyle marked by a mixture of customs, ideals, and cultures, and the troubled union between two complex realities. This paper addresses the importance of the literature produced by Latinos in the U.S., since their writings point out the contributions of Latino immigration to American cultural life and society.

Keywords: Frontiers; Identity; Latino Literature in the United States.

\section{REFERÊNCIAS}

ANZALDÚA, Gloria. Borderlands/La Frontera: The New Mestiza. 2. ed. San Francisco: Aunt Lute, 1999.

ARTEAGA, Alfred. Chicano Poetics: Heterotexts and Hybridities. Cambridge: Cambridge University Press, 1997.

GÓMEZ-PEÑA, Guillermo. The New World Border: Prophecies, Poems, and Loqueras for the End of the Century. San Francisco: City Lights, 1996.

MEDINA, Manuel. 2005. Disponível em US Latinos: <http://modernlanguages.louisville.edu/ spanish/classes/uslatino> Acesso em: 10/12/2008.

MCILVOY, K. (Editor in Chief). Puerto del Sol, Las Cruces, NM, v. 39, n. 2. 2004.

ORTEGA, Rafael Clemente. Anthology of Chicano Literature. Bristol, TN: Tara, 1 ed. v. 1. 2001.

SILVA, Tomaz Tadeu da (Org.). Identidade e diferença: a perspectiva dos Estudos Culturais. Petrópolis: Vozes, 2000.

http://www.latinamericanstudies.org/latinos/joaquin.htm.

Submetido em: 10/12/2008

Aceito em: 10/08/2009 
